\title{
POVERTY, MINORITIES, AND RESPECT FOR LAW
}

\section{J. SKELlY WRIGHT*}

The lot of the black man in the American ghetto, like slavery itself, will shame our history. Nor will our treatment of the poor Mexican American, the Puerto Rican American, or even the American Indian improve our image. The details of the discrimination in housing, in employment, and in those dreadful slum schools need not be repeated here. Suffice it to say now that we are reaping what we have sown. The continued discrimination and poverty in the ghettos are producing, in ever increasing numbers, minority youth who have never had a fair chance from the day they were born-young people who more and more are turning to a life of crime.

While American youth of all races cry out against the social injustice in our system, the victims of that injustice, the children of the ghetto, begin to prey on middle class America on the streets of every city in this land. Crime in the street has become an accepted fact of life for all of us.

Instead of recognizing its guilt for the injustice that breeds crime and eliminating the living conditions that inevitably produce it, the aroused Establishment has satisfied itself with half measures heavily. larded with rhetoric and patronizing slogans directed at the disenchanted, mostly poor minorities to encourage obedience to law, such as: "Respect the law-it respects you" and "No man is above the law and no man is below it." When confronted with this kind of Babbittry, the poor and the concerned youth of this country have a right to ask: "Does the law really respect those who do not have the political muscle to make the law?" Or, as Robert Kennedy put

- Judge, United States Court of Appeals for the District of Columbia Circuit. Brainerd Currie Lecturer 1970. 
it, there is a reason why the "poor man looks upon the law as an enemy . . . . For him the law is always taking something away."

As we enter the decade of the 1970s, I suggest we lawyers discard the slogans of the past and attempt some introspection on our profession, to examine the areas where the law has failed, where the pretense has been exposed by the practice, where indeed the law has actually been an arm of injustice. As a by-product of this effort we may come to understand why increasing numbers of the more able and sensitive law graduates today-those who have an alternative-are opting not to join the Establishment law firms to practice Establishment law.

\section{The POOR IN THE COURTS}

The proud boast of "Equal Justice Under Law" can be a delusive concept as it relates to the poor. For a law may be consistently and evenly applied and yet work a hardship on a particular class. Anatole France's much-quoted, scornful observation makes the point well: "The law, in its majestic equality, forbids the rich as well as the poor to sleep under bridges, to beg in the streets, and to steal bread." The point is that some of our laws are subjected to their greatest moral challenge when they are applied to the poor, particularly when past or present discrimination, legal or illegal, has been a major factor in keeping minorities in poverty.

Any assessment of an area where the law has failed as an instrument of justice should begin with the courts. It is true that the Warren Court in particular was sensitive to the legal problems of the poor. It announced broad new principles requiring state and federal courts alike to provide counsel ${ }^{2}$ and transcripts for indigent defendants, ${ }^{3}$ at least in felony cases. It eliminated the poll tax as a prerequisite to registration and voting. But these and other advances, great as they are, hardly help the poor in the police courts, the small claims courts, and the landlord and tenant courts of this country. And it is in these courts that the poor most often find themselves; it is in these courts that the poor get short shrift.

The police courts, sometimes euphemistically called magistrate's

1. Law Day Address, University of Chicago, May 1, 1964, ciled in P. WALD, LAW AND POVERTY: 1965 at $6 \mathrm{n} .13$ (1965).

2. Gideon v. Wainwright, 372 U.S. 335 (1963).

3. Griffin $v .11$ inois, 351 U.S. 12 (1966).

4. Harper v. Virginia Bd. of Elections, 383 U.S. 663 (1966). 
courts or municipal courts, often are hardly courts of law at all. They are in reality, as their name implies, extensions of the police. lt is into such courts that the poor are brought uncounselled and charged with such crimes as vagrancy, loitering, and no visible means of support-the modern equivalents of sleeping under bridges and begging in the streets. One of the principal purposes of these courts seems to be purely esthetic-to keep people we would prefer not to see off the streets. But as Professor Caleb Foote has pointed out, they also provide the magistrate with "an almost unchecked opportunity for arbitrary oppression or careless cruelty."'s

Most of the police courts and even some juvenile courts keep no record of their proceedings, so to that extent we are spared transcripts of what actually took place when the defendant or the child was before the judge. Recently there came across my desk a short transcript of the proceeding of a juvenile court in California dealing with a young Mexican American boy in the presence of his mother and father:

September 2, 1969

10:25 a.m.

\section{STATEMENTS OF THE COURT}

THE COURT: There is some indication that you more or less didn't think it was against the law or was improper. Haven't you had any moral training? Have you and your family gone to church?

THE MINOR: Yes, sir.

THE COURT: Don't you know that things like this are terribly wrong? This is one of the worst crimes that a person can commit. 1 just get so disgusted that I figure what is the use? You are just an animal. You are lower than an animal. Even animals don't do that. You are pretty low.

I don't know why your parents haven't been able to teach you anything or train you. Mexican people, after 13 years of age, it's perfectly all right to go out and act like an animal. It's not even right to do that to a stranger, let alone a member of your own family. I don't have much hope for you. You will probably end up in State's Prison before you are 25, and that's where you belong, anyhow. There is nothing much you can do.

1 think you haven't got any moral principles. You won't acquire anything. Your parents won't teach you what is right or wrong and won't watch out.

***The County will have to take care of you. You are no particular good to anybody. We ought to send you out of the country-send you back to Mexico. You belong in prison for the rest of your life for doing things of this kind. You ought to commit suicide. That's what I think of people of this kind. You are lower than animals and haven't got the right to live in organized society-just miserable, lousy, rotten people.

5. Foote, Vagrancy Type Law and Its Administration, 104 U. PA. L. Rev. 603, 645 (1956). 
There is nothing we can do with you. You expect the County to take care of you. Maybe Hitler was right. The animals in our society probably ought to be destroyed because they have no right to live among human beings. If you refuse to act like a human being, then, you don't belong among the society of human beings.

MR. LUCERO: Your Honor, I don't think I can sit here and listen to that sort of thing.

THE COURT: You are going to have to listen to it because I consider this a very vulgar, rotten human beins.

MR. LUCERO: The Court is indicting the whole Mexican group.

THE COURT: When they are 10 or 12 years of age, going out and having intercourse with anybody without any moral training-they don't even understand the Ten Commandments. That's all. Apparently, they don't want to.

So if you want to act like that, the County has a system of taking care of them. They don't care about that. They have no personal self-respect.

MR. LUCERO: The Court ought to look at this youngster and deal with this youngster's case.

What appalls me is that the Court is saying that Hitler was right in genocide.

THE COURT: What are we going to do with the mad dogs of our society? Either we have to kill them or send them to an institution or place them out of the hands of good people because that's the theory-one of the theories of punishment is if they get to the position that they want to act like mad dogs, then we have to separate them from our society.

Obviously this is an exceptional case. Certainly few judges address anyone-even a poor Mexican American - as this judge did. It is not improbable, however, that in areas where poor Mexican Americans are thought to present a problem, some judges think, but are restrained enough not to say, what this judge did. If this youngster's family had been affluent, there would have been no talk about Mexican Americans being mad dogs. A psychiatrist would have been called in and some plan for treatment of the child submitted to the court for its consideration. After a respectable period of time had elapsed, the case probably would have been closed. This unfortunate case-this little courtroom drama-is at once a most eloquent and a most depressing demonstration that it is the twin curses of poverty and race which often spark the engines of injustice.

The small claims courts treat the poor man's property like the police courts, and sometimes the juvenile courts, treat his soul. Originally designed to help the poor protect themselves against unscrupulous merchants, now small claims courts are primarily 
collection agencies. Instead of a court where a poor man could pay small fees and bring his own case, without a lawyer, against a merchant who had defrauded him, small claims courts now are used almost entirely by merchants to collect from the poor. Judgments are taken primarily by default, property is seized and sold without notice, deficiency judgments are obtained; and salary garnishments are issued. Suddenly the poor man finds that the money paid on the purchase is gone, the property is reclaimed, and he is out of a job because his employer prefers not to be bothered with garnishments. Is it any wonder that the poor are not entirely satisfied with the assurance that the law respects them?

No discussion of the courts and the poor would be complete without some reference to the landlord and tenant courts. While ancient in origin, today these courts deal primarily with urban slum property, and their judgments are enforced literally and physically by evicting the slum dweller and his family into the street. These evictions are by no means all related to nonpayment of rent. Because rental property for the poor is relatively scarce, slumlords ordinarily rent on a month-to-month basis rather than a long-term lease so that tenants who are so indiscreet as to complain to local authorities about minor housing violations-like no heat, no water, or a leaky roof-can be quickly evicted.

Retaliatory evictions are only part of the formidable arsenal of weapons at the command of the slumlord. While most cities have housing codes, the procedure for correction of violations has left much to be desired. The slumlords' rapport with the housing authorities often means little effective inspection by officials, and complaints often result in nothing but retaliatory evictions. Even when court proceedings for enforcement are brought, many judges have not bcen eager to enforce the housing codes. The poor simply are not important people whereas the slumlords apparently are.

Thus we see that in the police courts, the small claims or consumer courts, and the landlord and tenant courts, the poor usually receive the back of the hand. And, unfortunately, these are the only courts the great majority of the poor ever encounter. To them these courts are places to be avoided at all costs. To them these courts must be something akin to the English courts of 1849 as Charles Dickens described them in Bleak House:

[The courts are places] which give to - 's nied might, the means abundantly of wearying out the right; which so exh: finances, patience, courage, hope, 
so overthrow the brain and break the heart; that there is not an honourable man among its practitioners who would not give-who does not often give-the warning, "suffer any wrong that can be done you, rather than come here!"'

\section{Education AND THE POOR}

The importance of education has long been an article of faith in this country; yet even in this area the law, as distinguished from the courts themselves, has been largely counterproductive. Education has been the cornerstone of the melting pot concept of American life. Jefferson felt that education was the only "sure foundation . . . for the preservation of freedom," "without which no republic can maintain itself in strength." Washington," Madison, ${ }^{10}$ and John Adams $^{11}$ concurred in Jefferson's estimate of education as the indispensable cornerstone of a democratic society. The critical role of education in contemporary society nceds no documentation. As the Supreme Court said in Brown v. Board of Education," "In these days, it is doubtful that any child may reasonably be expected to succeed in life if he is denied the opportunity of an education."'13

Against this background depicting the primacy of education among our economic, political, and social needs, it is difficult to understand why the law has not played a greater role in the advance toward this societal goal. Specifically, as it relates to our minority groups, particularly the Negro, the performance of the law has been less than edifying. In the era before the Civil War the law in some states actually made it a crime to teach a black man, woman, or child to read and write. ${ }^{14}$ The motivation for such laws is obvious: ignorant blacks would have no basis for hoping or even wanting to improve their lot. There is reason to believe that this motivation

6. C. Dickens, Bleak House 3 (1951 ed.).

7. Letter from Thomas Jefferson to Whyte, Aug. 13, 1786, in 5 Writings of Thomas JEFFERSON 396 (Berg. ed. 1907).

8. Letter from Thomas Jefferson to John Tyler, May 26, 1810, in 12 WRITINGS OF THOMAS JEFFERSON 393 (Berg. ed. 1907).

9. See, e.g., Letter from George Washington to Samuel Chase, Jan. 5, 1785, in Writings OF GEORGE WASHINGTON 27 (Bicentennial ed. 1938).

10. Letter from James Madison to Thomas W. Gilmer, Sept. 6, 1830, in ThE Complete MAdISON 314-14 (Padover ed. 1953).

11. See Adams, Dissertation on the Canon and the Feudal Law (1765), in 3 Worxs of JoHN ADAMS 455-56 (Charles Francis Adams ed. 1851).

12. 347 U.S. 483 (1954).

13. Id. at 493.

"i4. See S. Elxins, SLAvery 60 (1959). 
persists in some degree with some people even today and accounts, at least in part, for the inferior education provided in the segregated slum schools.

With Reconstruction came schools for blacks. But it was not long before it became clear what type of schools they would be. With the sanction of the Supreme Court itself, blacks were segregated from the mainstream of education into schools that were inferior in almost every conceivable way to those attended by whites. The education black children received in such schools hardly equipped them for the social mobility which has always been the legitimate aspiration of all Americans. Such schools, like the laws against educating blacks at all, were designed for, and succeeded in, keeping the great mass of black people in their place-economically, politically, and socially.

With Brown $I$ the slow process of desegregation began. And after the expenditure of enormous effort, the end is not yet in sight. lndeed, we may be entering a period of resegregation impelled by the fear that desegregation, if continued in the South, may spread to the slum schools in the North and West. The action of the Senate after Senator Ribicoff's speech ${ }^{15}$ pleading guilty for the North and West to hypocrisy in insisting that the South alone desegregate was a straw in the wind. Senator Ribicoff's point, of course, is that the Senate was morally, if not legally, bound to take action to end discrimination in public schools wherever it existed. Actions in Congress since the Senate passed the Stennis Amendment ${ }^{16}$ following the Ribicoff speech raise questions whether, instead of attempting to end the immoral, if not illegal, ${ }^{17}$ discrimination in the public schools of the North and West, we are going to permit immoral and illegal discrimination in ghetto schools in the South to continue-in spite of the desegregation command of the Supreme Court in Brown and the literally dozens of other cases implementing that command. ${ }^{18}$

We are assured that the children in the ghetto schools will not suffer from segregation and that Congress will appropriate

15. 116 CoNG. Rec. 1461-64 (daily ed. Feb. 9, 1970).

16. The text of Amendment No. 463 can be found at 116 CoNG. Rec. 642 (daily ed. Jan. 27, 1970). Passed Senate, 56-36. 116 Cong. Rec. 1926 (daily ed. Feb. 18, 1970).

17. See, e.g., Keyes v. School Board, 303 F. Supp. 279 (D. Colo. 1969).

18. See, e.g., Northcross v. Board of Educ., 397 U.S. 232 (1970); Carter v. West Feliciana Parish School Bd., 396 U.S. 290 (1970) (per curiam); Green v. County School Bd., 391 U.S. 430 (1968); Hall v. St. Helena Parish School Bd., 417 F.2d 801 (5th Cir.), cert. denied, 396 U.S. 904 (1969). 
money for use in ghetto schools to compensate for the detriment of segregation. Assuming the best of intentions, it is doubtful whether segregated slum schools can provide an equal educational opportunity to children irrespective of the amount of money expended on them. Education for children is more than reading, writing, and arithmetic. Particularly for children deprived of the normal educational, social, and emotional experiences which a stable family relationship provides, education includes association with peer groups from other cultures and other races. "Today it is a principal instrument in awakening the child to cultural values, in preparing him for later professional training, and in helping him to adjust normally to his environment." Moreover, on substantial psychological evidence the Supreme Court in Brown found: "To separate [Negro children] from others of similar age and qualifications solely because of their race generates a feeling of inferiority as to their status in the community that may affect their hearts and minds in a way unlikely ever to be undone."20

In place of desegregation, the promise of more money for slum schools to insure quality, but segregated, education may be illusory. It is also contrary to history and experience with schools for the poor. Every study of school systems in every part of the country, including the nation's capital, almost without exception shows that the slum school is always separate but never equal. The slum school is almost always overcrowded. It has the more inexperienced and lower paid teachers, more dilapidated buildings with less playground space, fewer library and other facilities, and, most importantly, a smaller annual per pupil expenditure than other schools. Ever since Plessy v. Ferguson ${ }^{21}$ in 1896, public schools have been constitutionally required to be at least equal, but this constitutional requirement has been honored only in its breach. The sad but revealing fact is, that the power structure of the community controls the school system and their children simply do not go to slum schools.

In 1965 Congress passed the Elementary and Secondary Education Act.22 Title I of that Act explicitly recognized that poor children in slum schools needed better than equal schools to

19. 347 U.S. at 493.

20. Id. at 494.

21. 163 U.S. 537 (1896).

22. 20 U.S.C. $\S \S 236-44,331-32 b, 821$ et seq. (Supp. IV. 1969). 
overcome the crippling effects of their home and community environment, resulting with respect to Negro children, from historical discrimination against their forebears. ${ }^{23}$.Congress authorized the appropriation of money to be placed directly in the hands of local school districts to meet the "special educational needs" of disadvantaged children. ${ }^{24}$ The money is "to supplement, and not supplant, State or local funds." ${ }^{22}$ Under Title I the money is not to be used for general improvement of the school system or even to make the inferior slum schools equal. Title I naively assumes that school districts comply with the Constitution and provide equal educational opportunity for all children. The law limits the expenditure of Title I funds to poor children to provide additional educational assistance-compensatory education if you will-in order to raise their educational attainment to levels normal for their age. 26

Congress has appropriated over five billion dollars in Title I funds. ${ }^{27}$ As a recent study ${ }^{23}$ documents, much of this money has bcen diverted from the poor by state departments of education and school districts to other purposes, including the perpetuation of segregation. Technically this may not be stealing from the poor, but the effect on the poor is the same. This diversion of Title I funds has been going on systematically since the Act was passed and the money first appropriated; yet until recently no one in government-state, federal, or local-seemed greatly concerned. When the then United States Commissioner of Education, James E. Allen, announced that he would require Title I funds to be used for the purpose intended by the Act and exercise his right to cut off the funds to school districts not complying, Congress simply attached a idder $^{29}$ to legislation appropriating over one billion dollars for Title I purposes. The rider suspended the Commissioner's authority to withhold the funds on

23. Id. § 241(a).

24. Id.

25. 45 C.F.R. \$ $116.17(\mathrm{~g})(1970)$.

26. 20 U.S.C. $\$ 241$ e (Supp. 1V, 1969) provides "that payments to local educational agencies should be: "used for programs and projects . . . which are designed to meet the special educational needs of educationally deprived children in school attendance areas having high concentrations of children from low income families . . . '"

27. Washington Research Project \& NAACP Legal Defense \& Educational Fund, Title I of ESEA: 1s it Helping Poor Children? ii (rev. 2d ed. 1969).

28. Id. passim.

29. Pub. L. No. 91-230, § 109(a) (Apr. 13, 1970). 
any ground, including the fact that they were being diverted and used for illegal purposes, for a period of two years..$^{30}$

If the experience under Title I is any indication, much more than rhetoric will be required to provide quality education in our slum schools. Even the infusion of large amounts of money may prove a poor substitute for complying with the law as announced by the Supreme Court in Brown. In the meantime, it is becoming increasingly difficult to convince the black, the Mexican American, and the Puerto Rican minorities who are required to send their children to inferior, segregated slum schools that the Establishment respects the law. In their view, when the law, including the Constitution, pinches the Establishment's toe, it is simply, cynically, disregarded.

\section{Criminal Law, Corrections, and the Poor}

The law's inhumanity to the poor, and to minorities generally, is nowhere more apparent than in the administration of criminal justice; its hypocrisy is exposed in that area as well. While it is primarily the poor who are prosecuted for crime, the commission of crime is by no means limited to that group. Moreover, the crimes of the poor are in the main directly attributable to the degrading conditions under which they are born and bred in our urban ghettos. These conditions in turn are the direct result of the discrimination in housing, education, and employment for which the Establishment is responsible. Thus in a larger sense, the guilt for ghetto-bred crime is the system's guilt and the ghetto offender is the victim of the system. The President's Commission on Civil Disorders made the point this way: "What white Americans have never fully understood-but what the Negro can never forget-is that white society is deeply implicated in the ghetto. White institutions created it, white institutions maintain it, and white society condones it."'31

The law, of course, ignores this social guilt and proceeds directly against the immediate culprit. Even at this level the law's performance is decidedly uneven in at least three categories: (1) Crimes committed by the poor more often than not result in prosecution, whereas white collar and organized crime goes

30. "[A]ny finding of noncompliance with this clause shall not affect the payment of funds to any local educational agency until the fiscal ycar beginning July $1,1972 \ldots$. Id.

31. National Advisory Commission on Civil Disorders, Report 1 (1968). 
unreported, undetected, and unprosecuted. (2) Where both kinds of crimes do result in prosecution, the poor are convicted more often. (3) Even where both kinds of offenders are convicted, the poor go to jail more often. I shall consider each category seriatim:

(1) The crimes of the poor are highly visible. As one might anticipate, they relate primarily to the illegal acquisition of other people's property. Larceny, burglary, and robbery are typical poor man's crimes. While all such crimes do not result in prosecution, they are generally reported to the appropriate authorities by the victims. White collar and organized crime, on the other hand, is often consensual, such as bribery. With such crimes the danger of disclosure is relatively remote. More often white collar and organized crime has no victims other than the government, such as tax fraud. Even where crimes like tax fraud are eventually uncovered, with experienced counsel and sufficient funds these cases sometimes can be settled. The truth is that the sheer obviousness of crimes of the poor, together with the fact that the poor ordinarily have no connections with, or leads into, the police or prosecutor's office, makes their crimes more likely to be reported and prosecuted than white collar or organized crime.

(2) Several .studies ${ }^{32}$ suggest that where poor and well-to-do offenders are prosecuted, the conviction rate of the poor substantially exceeds that of the non-poor offender. This inference is derived from a comparison of the results of prosecutions where the defendant is detained in jail unable to make bond and those where the defendant is on bond before and during trial. Ability to make bail depends primarily on the happenstance of the defendant's financial resources. There is no reason to believe that the prosecutor routinely makes better cases against poor defendants; yet the studies show that the conviction rate for defendants in jail is almost twice that of bonded defendants. While to some extent factors other than inability to make bail can account for this remarkable statistic, it would be blinking reality not to admit that poverty alone is primarily responsible for many convictions. For example, inability to make bail hinders the preparation of a good defense. Moreover, a poor defendant does not have the resources to hire investigators or secure expert witnesses, even assuming a lawyer is appointed for him.

32. See Rankin, The Effect of Pretrial Detention, 39 N.Y.U.L. Rev. 641 (1964); Wald, Pretrial Detention and Ultimate Freedom: A Statistical Study, Foreword, 39 N.Y.U.L. REv. 631 (1964). 
Finally, an unbailed defendant may feel considerably more pressure to plead guilty to a lesser offense, particularly in view of the disadvantages mentioned above.

(3) Even more remarkable are the statistics, again from empirical studies, ${ }^{33}$ relating to the disposition of defendants after conviction. These studies show that defendants unable to make pretrial bail, that is primarily poor defendants, receive prison sentences twice as often as bonded defendants. What possible explanation, other than a bias against poverty, can there be for this aberration in the law? Whatever explanations there may be, compassion for the poor on the part of sentencing judges does not seem to be one of them. One cannot read these studies of the criminal law's treatment of the poor without recalling this poor man's prayer from Dickens: "Give us, in mercy, better homes when we're a lying in our cradles; give us better food when we're a working for our lives; give us kinder laws to bring us back when we're a going wrong; and don't set Jail, Jail, Jail, afore us, everywhere we turn."34

Once an offender is sentenced to prison, he becomes subjected to the tender mercy of our correction system. So much has been written about the cruelty and actual horror of some of our reformatories and penitentiaries it is difficult to understand how a civilized nation can continue to tolerate such a correction system. ${ }^{35}$ The governor of a state famous for its convict chain gangs is reported as saying that the only cure for the system was a better class of criminal. It would help too, I asșume, if we had a better class of governor.

In any event, it is into this system that offenders, many at a very early age and mostly poor, are plaeed-allegedly for rehabilitation. Actually, many of the correctional institutions are nothing more than crime schools turning out hardened criminals, bitter at society for real or imagined injustices. And the recidivism rate demonstrates beyond peradventure that, in addition to the immorality in treating

33. See note 32 supra.

34. C. Dickens, The Chimes 123 (1845).

35. A federal district court recently held that confinement in the prison system amounts to cruel and unusual punishment such that the state should be ordered to make "a prompt and reasonable start" toward reformation. The court stated: "For the ordinary convict a sentence to the .. . penitentiary today amounts to a banishment from civilized society to a dark and evil world completely alien to the free world, a world that is administered by criminals under unwritten rules and customs completely foreign to free world culture." Holt v. Sarver, 309 F. Supp. 362 (E.D. Ark. 1970). 
human beings as animals, our indifference to what goes on in prisons is a luxury that we are increasingly unable to afford.

The unconscionable aspect of the whole system of criminal law and correction is that the poor bear the brunt of it. The President's Crime Commission of 1967 showed that 90 percent of the youth of America have committed antisocial acts for which they could be committed by a juvenile court. ${ }^{36}$ Yet 95 percent of those actually committed are poor. ${ }^{37}$ Thus again it is primarily the poor who are started early in the criminal law cycle, processed through our correctional system, and turned out as dangerous criminals.

What happens to the non-poor who commit crime? "A wholly private and unofficial system of correctional treatment has long been available to the violent sons of the socially fortunate, ${ }^{138}$ according to Professor Richard Korn, a nationally known Berkeley criminologist. In a report to the Joint Commission on Correctional Manpower and Training, Professor Korn exposes the hypocrisy in a system where the poor get prison and the non-poor get help. ${ }^{39} \mathrm{Dr}$. Korn suggests that

[k]eeping children out of reformatories is a widely approved and worthy objective, irrespective of whether the children are rich or poor. The scandal lies in the fact that such alternatives are denied to the poor, through nothing more deliberate than the incidental fact of their inferior economic position."

\section{OTHER AREAS}

There are, of course, other areas where the law has been used as an instrument of injustice against minorities and the poor. I should like to make just a passing reference to two-the welfare laws and the Selective Service Act.

Welfare has long been considered the equivalent of charity and its recipients have been subjected to all kinds of dehumanizing experiences in the government's effort to police its welfare payments. In fact, over half a billion dollars are expended annually for

36. President's Commission on Liw Enforcement and Administration of Justice, The Challenge of Crime in a Free Society 55 (1967).

37. R. Carter, Middle Class Delinquency-An Experiment in Community Control. (1968) (a report to the President's Commission on Juvenile Delinquency and Youth Development).

38. Korn, Issues and Strategies of Implementation in the Use of Offenders in Resocializing Other Offenders, in JoINT COMmission ON CORRECTIONAL MANPOWER AND TRAINing, Offenders as a Correctional Manpower Resource 75 (1968).

39. Id.

40. Id. 
administration and policing in connection with the Aid to Families with Dependent Children program." Why such large sums are necessary for administration and policing has never been adequately explained. No such sums are spent policing the government subsidies granted to farmers, airlines, steamship companies, and junk mail dealers, to name but a few. The truth is that in this subsidy area society has simply adopted a double standard, one for aid to business and the farmer and a different one for welfare. As Professor Charles Reich of Yale says: "It is a double standard from the moral point of view and a double standard from the legal point of view. There is a law for the poor and a law for the rest of us. Receipt of government aid by the poor carries a stigma, whereas receipt of government aid by the rest of the economy has been made into a virtue."12

This policing of welfare recipients is not only degrading to the poor; it is self-defeating. Instead of assisting in restoring dignity to the recipients, policing tends to destroy their self-respect and thus tends to reinforce their dependence. Other than the aged and the infirm, people on welfare generally are not dead-end charity cases. Many heads of families are temporarily poor because of dislocations in the economy over which they have no control. If the skills which formerly supported them. are no longer in demand, they must be taught new skills and must be supported in the interim. In fact, the great poverty problem in the urban ghetto results to some extent from economic dislocation. The need for farm workers has diminished markedly because of mechanization and the government's farm subsidy policies. Large numbers of black farm workers have been driven to the urban ghettos where, through no fault of their own, they cannot support families. Thus women with dependent children are on welfare. To subject these women and children to an army of snoopers seeking to find a man in the house has been a counterproductive and reckless cruelty..$^{4}$

Little needs to be said about the draft law's injustice to the poor. The poor are generally less familiar with the intricacies of the law and the loopholes in the regulations than the more affluent. Suffice it to say that the poor and the black minorities are carrying much

41. National Center for Social Statistics, Report A-7 (CY 68) (1968).

42. Reich, Social Welfare in the Public-Private State, 114 U. PA. L. REv. 487, 491 (1966).

43. See generally Barrett, The New Role of the Courts in Developing Social Welfare Law, 1970 DUKE L.J. 1, 17-22. 
more than their share of the fighting and dying in Vietnam. I am not pointing the finger. Nor am 1 supporting the war. I am simply stating a fact that no doubt bears some relationship to the poor's socio-economic status.

\section{THE DANGER OF DISCONTENT}

History, including our own, confirms that the use of law to maintain an unjust status quo sows the seeds of discontent. Edmund Burke, the great friend of America, in a letter dated October 8, 1777, to his friend and colleague in Parliament, Charles James Fox, commented on the cause of the great historical event then in progress: "People crushed by law have no hopes but from power. If laws are their enemies, they will be enemies to law; and those who have much to hope and nothing to lose will always be dangerous, more or less." $" 44$

Recent national polls ${ }^{45}$ reveal the depth of the minority discontent with the legally enforced status quo in this country. These polls show that 40 percent of the black youth believe there is no real hope for redress of their grievances through law. We, of course, nced no polls to tell us that many non-poor, non-minority youth are disenchanted with the system and with the unjust status quo of which they are among the beneficiaries. Whether this disenchantment is fueled, at least to some extent, by guilt feelings is a subject now absorbing the psychiatrists. The rest of us must determine what to do about the unjust status quo and the law that supports it.

First of all, "dropping out" or simply ignoring the problem or pretending that it does not exist is not the answer. It may provide a certain amount of insulation from reality, but the insulation may be short-lived. Moreover, dropping out is the easy way out. It bespeaks a kind of cowardice and an insensitivity which I would prefer not to associate with this generation of American youth. Nor is bombmaking or bomb-throwing the answer. Let's face it; the system really is not that bad. Changes it does need, but blowing it up would be going a bit too far. In any event, the system is fully supported by the broad base of the American people. 1 seriously doubt that it is about to succumb to a few homemade bomb throwers.

On the other hand, our reaction to the increasingly violent

44. E. Burke, Letters Speeches AND Tracts on IRISH AffalRs 95 (1881).

45. Time, Apr. 6, 1970, at 28. 
rhetoric we hear today ought not to be paranoid and largely baseless fear, but rather an understanding of the increasingly bitter disillusionment which that rhetoric represents-disillusionment with the disparity between this country's lofty pretense and the shameful reality. We should realize and admit that some of our values and institutions are afflicted with a profit-based morality. They are sick, perhaps even critically so. They are not yet moribund, but they do need assistance. They need a great deal of help, and they need it now.

\section{LAWYERS As SOCIAL ENGINEERS}

The young lawyers of this country provide the promise for peaceful change-change in unjust laws which protect an unjust status quo. 1 emphasize young lawyers because once a lawyer joins the Establishment, for a variety of reasons his sensitivity to the kind of injustice discussed above is somehow often diminished. I emphasize lawyers because traditionally lawyers in this country have of ten been the moving spirit-the cutting edge-behind social and political, as well as legal, change. 1 focus on lawyers too because the present crisis we face, in dealing with poverty, urban blight and congestion, violence, racial hatred, inadequate education, housing, and health facilities, is intimately legal in nature. As the great Roscoe Pound has said, lawyers are social engineers and law is the medium through which society attains its goals. ${ }^{46}$ It is also the means by which society changes its goals when political and social realities decree change. DeToqueville recognized this fundamental truth more than a century ago when he observed: "[I]n a modern democracy social problems become translated into legal problems-if the democracy coheres. . . ."47

1 would like to consider specifically how lawyers, and particularly young lawyers and law students, can work to use law as an instrument for social justice. When I speak generally of "the law," I refer to it in its broadest and most inclusive sense. In Llewelyn's terms, law is "what officials do, do about disputes, or about anything else . . . [with] a certain regularity in their doing-a regularity which makes possible prediction of what they and other officials are about to do tomorrow."48 Lawyers can affect what

46. See, e.g.. R. Pound, Interpretations of Legal History 152-53 (1923).

47. Law in a Changing america xi (G. Hazard ed. 1968).

48. K. Llewelyn, The Bramble Bush 13 (1951). 
officials do at every level, from the city court judge to the federal administrator, from the congressman to the welfare worker. There has been much debate about the effectiveness of lawyers' activities in changing the lives of the poor to any significant extent.4 In my view, it is important to keep in mind, first, the wide variety of arenas in which lawyers can usefully represent the interests of the poor, and, second, the complex interrelationship of these activities.

In his most traditional role, a lawyer represents an individual client on one specific problem. The poor have a desperate need for legal service in this form: the tenant evicted by court order without notice, the worker fired because his wages have been garnished, the parent whose child has been suspended from school, the welfare recipient whose benefit has been sharply reduced-all may have no idea what their rights are, what they are entitled to, or what remedies are even potentially open to them. To most poor people, such action often appears as mysterious as it is sudden, as arbitrary as it is disastrous.

The presence of a lawyer in these situations would yield two consequences; neither is startling nor surprising and yet both are fundamentally significant. First, the lawyer can explain the proceedings, including the rights and the duties of all participants, and ensure that his client reeeives his due. In short, the lawyer can "secur[e] the poor in the knowledge that they get an even procedural break before the law."50 If lawyers were available to counsel poor people, the poor would be able to confront important crises with some feeling that they could control the quality, direction, and independence of their, lives. ${ }^{51}$ Second, legal representation of poor people in routine, individual cases would have a substantial impact on the way others dealt with the poor. The poor are often the victims of sharp dealing because people assume that the poor do not know their rights, are insecure, and can be easily intimidated. If the poor have lawyers, however, business as usual won't work; people serving the poor, knowing legal advice and representation is available even to poor people, will have to conduct their affairs according to law.

Ensuring that a poor man's grievances are properly aired and

49. See, e.g., J. Carlin, J. Howard \& S. Messinger, Civil. Justice and the Poor (1967); Cahn \& Cahn, The War on Poverty: A Civilian Perspective, 73 YALE L.J. 1317 (1964); Hazard, Social Justice Through Civil Justice, 36 U. ChI. L. REV. 699 (1969).

50. Hazard, supra note 49 , at 712 .

51. See Cahn \& Cahn, supra note 49. 
that the existing law is applied and followed may be a meager achievement indeed if the rule of law to be applied is itself weighted against the poor. But an airing of grievances is the necessary first step in changing the substantive rules of law which affect the poor. The adversary system assumes active representation of all interests at all times. In the past the poor have rarely been represented; their claims have rarely been presented effectively and insistently, either to courts or to other official bodies. Courts have not been aggressively challenged with the ways, often subtle, that different rules of law unfairly affect the poor. As a consequence old rules, no longer justifiable on their own terms and out of date with present needs, are not modified; new rules are formulated without sufficient awareness of their impact upon the poor. Only the repetition of routine and consistent legal representation of the poor can be counted upon to educate courts to the need for change and to make them receptive to new arguments and approaches.

Realism counsels caution in predicting how fast courts will move in remedying the ever clearer discrimination and burden which various laws place upon the poor. Courts are often uncertain in the face of new challenges. By its nature, case-by-case adjudication brings change slowly. But because change tends to come slowly, it is doubly important for it to proceed constantly. The lawyer's commitment must be not only to remedy the present crisis by pressing for as rapid change as possible, but also to press continuously for evolutionary change to ensure that just grievances receive redress as they occur and are not allowed to fester and grow until their severity threatens to make a mockery of justice.

In addition to protecting the poor from the avarice and insensitivity of private parties, lawyers can also prevent officials and government agencies from denying the poor rights under government programs. For there are government programs which have begun to effect some redistribution of income and which are designed to help poor people. In enacting and administering these programs, officials often make sweeping assertions promising vast accomplishments. Too often, however, well-intentioned government aid programs founder on inadequate funding or on an unresponsive and uncooperative bureaucracy bent on pursuing its own interest rather than the interests of the poor. In effect, the system tries to have it both ways-we won't give up our proud boasts but we are unwilling as a society to expend the effort or money neeessary to make good 
on these commitments. Lawyers are in a position to make us "put up or shut up" by exposing hypocrisy and seeking consistent enforcement of statutes and regulations which make promises to the poor.

Last year's national concern over hunger in America makes this point well. Officials opposed to liberalized food stamp or commodity distribution programs could not, in affluent America, openly work against hungry people. Rather they simply denied that hungry people existed in this land of abundance. Citizens' reports and lawsuits refuted these claims. ${ }^{52}$ As a result, court decrees, administrative reorganization, and new congressional action have substantially widened the nation's efforts to reduce, if not eliminate, hunger.$^{53}$ The country could not back away or disown its rhetoric, so it is moving to make its rhetoric approximate reality.

Day-to-day implementation of legislative policy-either by an independent regulatory agency or by an executive department-ordinarily is very sensitive to the responses and reactions of the affected citizens. In fact, for many government programs, the interstitial legislation involved in rule-making and regulation by the various agencies and departments may often be far more important to the people concerned than the original congressional action. Special interest groups influence the formulation of the rules. This is as it should be. In a democracy, governmental institutions must be conscious of the desires of the people and particularly of groups whose interests are directly affected by government action..$^{54}$ As the government bureaucracy grows and power is increasingly delegated by an overworked legislature to bureaucracies, we need more, not less, infusion of public sentiment into the operations of government. ${ }^{35}$

My concern here is that this whole system operates on the assumption that all interests in society are represented, that all interests give voice to their concerns, and that the interests of one group are not given undue weight in the final decision. These assumptions do not square with the facts, at least where the poor

52. See Citizens' Board of Inquiry Into Hunger and Malnutrition IN the United States, Hunger, U.S.A. (1968).

53. See Jay v. United States Dep't of Agriculture, 308 F. Supp. 100 (N.D. Tex. 1969).

54. See Administrative Procedure Act § 4,5 U.S.C. § 553 (Supp. IV, 1969).

55. Cf. Office of Communication of United Church of Christ v. FCC, 359 F.2d 994 (D.C. Cir. 1966). 
are involved. Quite predictably, the interests of the poor are given very little effective representation on specific issues and problems at all levels of government. This situation has begun to change. The war on poverty and the civil rights movements have moved the problems and inequities into the limelight and focused national attention on them..$^{56}$ But generalized concern and rhetorical posturing are not enough. Concern and rhetoric must be turned into practical effectiveness.

Practical effectiveness means active participation in administrative rule-making proceedings by representatives of the poor ${ }^{57}$ As the very existence of many large Washington law firms indicates, businessmen have found lawyers to be effective in this role. Nor is participation in the formal administrative hearings the end of the matter. Representatives of the poor must constantly bring administrative failures to the attention of the bureaucracy, the legislature, and the public. ${ }^{58}$ Government programs are on-going operations; new abuses must be corrected, and agencies must be made constantly to respond to new problems as they develop and to devise new strategies as old ones demonstrate their ineffectiveness.

Although this discussion has focused upon the need for effective representation of the poor in courts and before administrative agencies charged with administering or enforcing laws which affect the poor, the poor need more vigorous representation in the legislature as well. Legislative committees, indeed the legislative process itself, have a strong adversary flavor to them. Congressmen and state legislators are elected only every few years and run for office on generalized and wide-ranging platforms. Legislation implementing the platform is subjected to scrutiny through committee hearings and presentations made to individual legislators.

Well-heeled special interest groups send lawyers and representatives to hearings and to individual legislators with exhaustive analyses of proposed legislation. The poor, unorganized, unable to pay for such help, and often unaware of proposed laws

56. See Barrett, supra note 43, at 15-16.

57. See Bonfield, Representation for the Poor in Federal Rulemaking, 67 MiCH. L. REv. 511 (1969). Senator Kennedy has introduced legislation which would establish a Public Counsel Corporation to serve unrepresented segments of the public. Project, Federal Administrative Law Developments-1969, 1970 DUKE L.J. 111 n.77.

58. See generally Cahn \& Cahn, The New Sovereign Immunity, 81 Harv. L. Rev. 929 (1968). 
which will seriously affect their lives, have rarely in the past been able to speak out or lobby effectively on specific pieces of legislation." It is no wonder that they have not fared well. Lawmakers, badgered and importuned by lobbyists, have a habit of assuming that silence from a specific interest group represents approval or acquiescence. This assumption may be justified when dealing with the National Association of Manufacturers, but it is obviously nonsense when the poor are involved.

- In fact, as a practical matter, legislative hearings are structured in ways to make them inaccessible to the poor. Committees generally require witnesses to appear in person, usually in Washington or at a state capital in the case of a state legislature. Printed or mimeographed copies of the witnesses' statements must be provided. A lawyer usually holds the witness' hand while he testifies and stands ready to ward off any attacks from unsympathetic legislators. Poor people obviously have neither the time, the expertise, nor the resources to present their position effectively. Lawyers, representing and advising various organizations of poor people, could substantially alleviate this significant gap in the participation of the poor in the legislative process.

Of course, young people can have an even more direct impact upon government through politics. The campaign of Eugene $\mathrm{McCarthy}$ for President demonstrated the vast political muscle represented by young people willing to engage in hard political campaigns. The impact of those talented McCarthy campaigners was national in 1968. If young people focused their efforts on congressional elections in 1970 and 1972, Congress would be a vastly different place. Moreover, if a congressman or state legislator knew that his record on the pressing problems of the cities and the poor was being watched by hundreds of potential young campaign workers, those legislators might become vastly different men. In short, I applaud all young people and young lawyers who translate their social concerns into effective political action. Demonstrations and bearing witness may be good for the soul, but, quite understandably in a democracy, there is nothing that moves the system like political muscle.

\section{Programs}

While young people, including lawyers, may use politics as an effectivc instrument for social reform, lawyers, as lawyers, have an

59. See generally Barrett, supra note 43. 
additional responsibility. I have already indicated the important roles which young lawyers can play in using law as a tool of social change. Now I would like to consider how law students can get involved in these efforts. Initially, it seems to me that the need for using law students in these efforts is great indeed. It should now be apparent that the number of lawyers required to serve the poor adequately is very large. In fact, it may be that realistically the law schools are not graduating enough lawyers to serve the expanding demand created both by growing population and by growing insistence that legal counsel be available to far more people than in the past. Law students, after their first or second year, can fill this need to some extent, and incidentally obtain valuable experience, by acting as lawyers for the poor. At least nine states now allow thirdyear students to represent indigent persons charged with misdemeanors. ${ }^{60}$ Some courts are also allowing representation of indigent civil litigants by third-year law students. ${ }^{61}$ These programs should be expanded throughout the country, and the pressure for such changes will have to come from the law students through their law schools.

Short of doing actual court work, many schools have a variety of clinical programs which allow students to become involved in actual legal matters in the community. The form of these programs varies widely. Some schools operate neighborhood law offices staffed by lawyers who use students as assistants. ${ }^{62}$ Other schools run programs which provide free advice to prisoners on the legal validity of claims they seek to raise through habeas corpus petitions. In fact, several courts, both federal and state, have actively sought such assistance from law schools. ${ }^{63}$ These programs provide the indigent prisoner with an understanding of the legal merits of his case and the operation of the legal system, while aiding the courts in appraising the legal claims made by the prisoners.

60. Those states are Illinois, Indiana, Iowa, Kansas, Maine, Nebraska, Ohio, Pennsylvania, and Wyoming. See Clinical Education and the Law School of the Future, 20 U. Chi. Conf. Series 224 (Kitch ed. 1969).

6I. See id.; Broden, A Role for Law Schools in OEO's Legal Services Program. 4I Notre Dame Law. 898 (1966); Monaghan, Gideon's Army: Student Soldiers, 45 Boston U.L. Rev. 445 (1965).

62. See Silverberg, Law School Legal Clinics: A Sample Plan; Their Legal Status, 117 U. PA. L. Rev. 970, 976-78 (1969); Note, Neighborhood Law Offices: The New Wave in Legal Services for the Poor, 80 HARv. L. REV. 805, $841-43$ (1967).

63. Silverberg, supra note 62. 
Law students can also run programs to advise various community groups and organizations of the poor of their legal rights and to assist such organizations in presenting their grievances to relevant officials. ${ }^{\text {gh }}$ The vast reservoir of talent represented by the law students of this country has only begun to be tapped. 1 urge all law students to realize that even before they graduate they have a responsibility to the profession and to the community to respond to the social needs of today. In addition, it may be that law schools and law students might develop an analogy to the year which a medical student spends as an intern at a hospital immediately after graduation. Law students might consider volunteering a year of service as a lawyer to a tenant union or a consumer group or an antipollution organization immediately after graduation. Such a program should not be mandatory, of course, but young law graduates might welcome an opportunity to devote a year to public service even if they desire to make their careers elsewhere.

Although this may sound surprising, I believe that law students also have a substantial responsibility to exert their influence on law firms to convince the firms to make meaning ful contributions toward representation for the poor. ${ }^{65}$ Law firms need law graduates. They should be made to understand and appreciate the social commitment of law students and young lawyers. Law firms must take notice of the ferment in the law schools. Indeed, many already are moving. And much of this commitment of law firm resources to so-called "pro bono" work has come as the result of pressure from law students.

Recently, students from at least eight law schools sent out questionnaires to all law firms who interviewed at their schools requesting information about the extent of the firm's pro bono work ${ }^{68}$ At some schools students rigorously followed up the questionnaires by close questioning of the firm's interviewers. If all law students insisted as a condition of working for a firm that the firm commit certain portions of its resources to pro bono work, a very substantial and dramatic beginning would have been made in attacking our social problems.

The importance of law students exerting pressure on law firms

64. See P. WALd, LAW ANd Poverty: 1965 at 89-95 (1965).

65. See generally Berman \& Cahn, Bargaining for Justice: The Law Students' Challenge 10 Law Firms, 5 Harv. Civ. Rights-Civ. Lib. L. Rev. 16 (1970).

66. Id. at 26 . 
is emphasized here because it seems vitally important that law firms, in their own self interest if not for moral reasons, become involved in representing the poor and in rooting out injustice. ${ }^{67}$ There are not nearly enough lawyers paid, either by OEO or foundations, to serve the many legal interests of the poor. Unless the resources and legal talent of the country's law firms can be tapped, and tapped to a substantial extent, we shall never be able to make good on our country's promise of justice for all. In addition, while OEO's Legal Services Program ${ }^{68}$ has dramatically increascd opportunities for young lawyers to devote themselves full time to public interest and poverty law, professional interest on the part of recent law school graduates exceeds the number of jobs. ${ }^{69}$ Young lawyers must be able to take jobs with law firms and still be in a position to cngage in substantial public interest work.

As indicated, many law firms are responding. Some law firms have set up "branch" offices in the ghetto neighborhood of their city and provided free legal assistance to indigents. Lawyers staff such an office on a rotating basis and are paid for working in the branch office exactly as if they were working on fee-paying business. Other firms have told their lawyers that they are free to spend a certain percentage of firm time, usually 10 or 15 percent, on pro bono work. One large Washington law firm has set up a. "public, service" department and has assigned one partner and one associate to it full time. All members of the firm will continue to devote a percentage of their time to pro bono projęcts, but their efforts will now be coordinated and supervised by people with full-time responsibility and commitment to these projects. Other firms have dcvised still other forms for their work in the public interest. Some simply accept suits, as a firm, in the public interest and charge no fee. Another has worked out an agreement with the local Neighborhood Legal Services Program to provide manpower on its projects as needed..$^{70}$

No one of these plans or programs is necessarily superior to any

67. See generally Boasberg, The Private Practice of Urban Law, 20 CASE W. RES. L. REV. 323 (1969); Brennan, The Responsibilities of the Legal Profession, 54 A.B.A.J. 121 (1968).

68. 42 U.S.C. $\S 2809(3)$ (Supp. IV, 1969).

69. See Berman \& Cahn, supra note 65 , at 17-20.

70. Many writers have debated the merits of various plans for law firm contributions to legal services for the poor. See Brennan, supra note 67; Frankel, Experiments in Serving the Indigent, 51 A.B.A.J. 460 (1965); Kirgis, Law Firms Could Better Serve the Poor, 55 A.B.A.J. 232 (1969); PyE \& GARRATY, The Involvement of the Bar in the War Against Poverty. 41 Notre Dame law. 860 (1966). 
other. In general, I would urge young lawyers and law students to convince firms to assign people to public service work full time for extended periods and to do it in the name of the firm. In this way a more thorough-going commitment of the firm to such work can be assured. Moreover, it is important for judges to know that the large and stable elements of the legal community are involved in public service law suits.

Beyond those efforts explicitly labeled "public service" or "pro bono," lawyers must as a profession begin to take the public interest into account in advising all their clients. ${ }^{7}$ Indeed, lawyers would render their clients far better service if they counselled against activities which run counter to the public interest. Where were the lawyers for the automobile industry several years ago when car safety and carbon monoxide pollution first began to be discussed within the industry? Would not the companies have fared better financially, politically, and morally if their counsel had forcefully advised them about the potential legal and regulatory consequences of ignoring safety and pollution problems?

I am talking here about the advice a lawyer gives his client before the fact-preventive legal advice. I do not seek to weaken the adversary system in the context of a court contest. But I do believe that the legal profession, as a profession, has an obligation both to itself and to society to take a much stronger stand-and perhaps even a public one-when a client seeks advice about a future course of action affecting the public interest. In those circumstances, the lawyer would serve the profession-and even the best interests of his client-if public interest considerations played a major role in his advice.

Nor are the lawyers who go to work in the legal departments of corporations and in the legal departments of government exempt from similar responsibility. These lawyers have an equally heavy duty to work for reform from the inside. Because they work for a single employer, they will not have complete freedom to do everything they desire. But simply because a lawyer works for a corporation or for a government agency does not mean that he can avoid his professional responsibility to see that his advice is influenced by a commitment to the public interest and social justice.

71. The debate on this question has spread beyond the legal profession to become a matter of general public interest. See, e.g., Riley, Influence, Picket Signs, and the Public Good: A Debate on the Lawyer's Role, Washington Post, Mar. 15, 1970, Potomac Magazine at 14. 
There are, of course, increasing opportunities for young lawyers to devote themselves full time to representing the poor. There are now Neighborhood Legal Services Programs in most major cities; hopefully, in the next few years, this program will expand substantially. Young lawyers constitute an effective lobby for expansion of this program, as well as the lifeblood of the offices which are already in existence. These programs have generally existed for a very short time, none longer than about six years. Yet their aggressive style of lawyering has already begun to make itself felt in significant ways. Three welfare suits have been won in the Supreme Court in the last three years, ${ }^{73}$ all brought by NLSP lawyers. OEO-funded lawyers in California have prevented a major cutback in health services for the poor ${ }^{74}$ and in our court NLSP lawyers have obtained free transcripts for indigents in appropriate civil cases. ${ }^{75}$ While these suits are dramatic, there is no way to record the accomplishments of these lawyers in terms of the thousands of poor people who for the first time received legal advice and went to court with a lawyer. And not surprisingly, a substantial majority actually won their cases.

Still other young lawyers have struck out on their own, setting up their own law firms with no government or foundation support. They accept a small proportion of fee-paying clients and use those clients to support themselves. The rest of their time is devoted to the practice of public interest law. ${ }^{76}$ Often these "private" practitioners of public law find themselves freer than those who are on the payroll of OEO or a foundation. Consequently, some of these young lawyers are registered lobbyists and appear regularly before congressional and state legislative committees to lobby for or against bills that have an impact on the poor.

Finally, it is noteworthy that many of these young lawyers are developing new legal frontiers. Thus one group of young lawyers has

72. 80 HARV. L. REV., supra note 62 , at 806 .

73. Goldberg v. Kelly, 397 U.S. 254 (1970); Shapiro v. Thompson, 394 U.S. 618 (1969); King v. Smith, 392 U.S. 309 (1968).

74. Morris v. Williams, 67 Cal. 2d 733, 433 P.2d 697, 63 Cal. Rptr. 689 (1967).

75. Lee v. Habib, Nos. $22203-4$ (D.C. Cir., Jan. 22, 1970).

76. Other young lawyers have chosen to set up law firms which focus on other strategies for helping poor people. One such firm in Washington plans to focus exclusively on appearances before federal administrative agencies. They will appear in rule-making proeeedings, and file suit if necessary, to ensure that federal bureaucrats do not, either by negligenee or by design, harm the interests of the poor. 
begun to seek ways to control the irresponsible exercise of power by large corporations. Raising novel questions of corporate law, they sought to place numerous propositions before the stockholders of General Motors at the annual meeting. Their efforts won partial success before the Securities and Exchange Commission. ${ }^{77}$ Perhaps even more importantly, they have received much publicity and have stimulated serious public debate on the proper control and responsibilities of our vast corporations. I can assure you that the officials of General Motors and other large corporations are listening. They all remember Nader, and soon there will be thousands of young lawyers like Nader trying to restore eeonomic order and social justice in this country.

\section{CONCLUSION}

It may be that I ask too much-I expect too much-from law students and young lawyers. They, like the young people in other disciplines, are not responsible for the injustice that exists in this country today. Today's youth are not responsible for the ghettos which disgrace our urban centers. They do not subscribe to the profit-based morality which sickens our society. But they do have a sense of mission-a mission to clean up the mess the older generation has visited upon them, indeed a mission to save the system from itself. Perhaps I read them wrong. In any event, they are our only hope. As Robert Kennedy has written:

Our answer is the world's hope; it is to rely on youth-not a time of life but a state of mind, a temper of the will, a quality of the imagination, a predominance of courage over timidity, of the appetite for adventure over the love of ease. The cruelties and obstacles of this swiftly changing planet will not yield to obsolete dogmas and outworn slogans. It cannot be moved by those who cling to a present that is already dying, who prefer the illusion of security to the excitement and danger that come with even the most peaceful progress. It is a revolutionary world we live in; and this generation, at home and around the world, has had thrust upon it a greater burden of responsibility than any generation that has ever lived. ${ }^{78}$

77. N.Y. Times, Mar. 20, 1970, at 1 , col.5.

78. R. Kennedy, To SeeK a Newer World 230 (1967). 
